\title{
洋上中継器（ASV）の開発
}

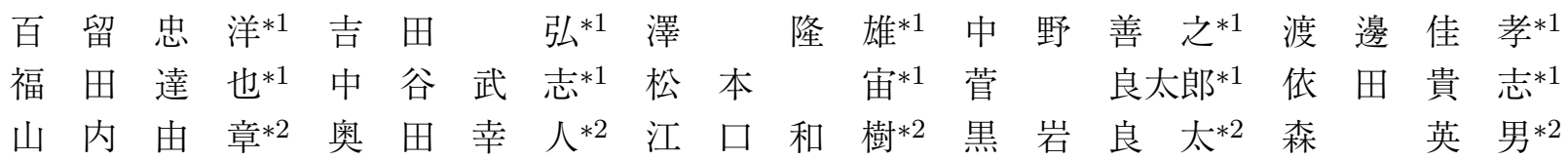

\section{Development of Autonomous Surface Vehicle}

Tadahiro Hyakudome*1, Hiroshi Yoshida*1, Takao Sawa*1, Yoshiyuki Nakano*1, Yoshitaka Watanabe*1, Tatsuya Fukuda*1, Takeshi Nakatani*1, Hiroshi Matsumoto*1, Ryotaro Suga*1, Takashi Yoda*1, Yoshiaki Yamauchi*2, Yukihito Okuda ${ }^{* 2}$, Kazuki Eguchi*2 ${ }^{* 2}$ Ryota Kuroiwa*2 and Hideo Mori*2

\begin{abstract}
JAMSTEC has operated autonomous underwater vehicles (AUVs) for scientific survey of seabed mineral resources. Conventionally, it is difficult for one support vessel to track plural AUVs in one operation. However, it takes a long time for one AUV to survey a large target area. To solve this problem JAMSTEC has developed an autonomous surface vehicle (ASV) with MHI. The vehicle instead of the support vessel, autonomously tracks AUV(s) and monitors its progress, enabling the simultaneous operation of multiple AUVs and thereby the survey of a larger target area within a given period of time. An important role of the ASV is to relay underwater communication and aerial communication because the underwater communication range is very small. ASV tracks AUV autonomously to keep the acoustic communication, and send AUV information to the support vessel by using radio waves.
\end{abstract}

Key Words: Autonomous Surface Vehicle, Multiple AUVs Operation, Mineral Resources Survey

\section{1.はじめに}

我が国は世界第 6 位の排他的経済水域を有し，その利活用が 期待されている。近年では海底鉱物資源に注目が集まっている が，これらの資源の探査や開発のためには海底下の状況を広範 囲にわたって調査する必要がある。 そのためには海底地形・水深 などの海洋デー夕を広範囲にわたり効率良く採取することが求 められる. しかしながら, 船舶による海洋調査だけでは労力や 時間がかかることから, この課題を解決するために, 自律型無 人探査機 (AUV：Autonomous Underwater Vehicle) [1] が開 発され調査の効率化, 省人化, 省エネルギー化がなされている. これらの AUVは, 主に巡航型で海底面付近に接近し, 高精度 に地形 ·地質 - 海底構造, 水温 - 塩分 - 圧力, $\mathrm{pH}$, 二酸化炭素 濃度等の様々な海洋データを取得することが可能であり, 年々 AUVの普及台数が増加している.ただし, AUVの測位や航行 中の状態監視, 情報取得のために支援船舶が追従し管制してい

原稿受付 2017 年 6 月 23 日

${ }^{* 1}$ 国立研究開発法人海洋研究開発機構

$* 2$ 三菱重工業株式会社

${ }^{* 1}$ Japan Agency for Marine-Earth Science and Technology

${ }^{* 2}$ Mitsubishi Heavy Industries, Ltd.

一本論文は有用性（実証実験分野）で評価されました。
るのが現状である.

現在, 海洋調査の効率を向上させるため, AUV の複数機同時 観測システムを構築する計画がある $[2]$. これは 1 隻の船舶によ り AUV を複数機展開して観測できる運用手法を構築しょうと するもので，これにより例えば海底資源の性質（海底熱水鉱床 であれば活動状況や成分等）をより精確に計測し，品質や賦存 量の推定に必要なデー夕を短時間で収集するなど高精度多項目 な海洋調査の効率向上が可能になる。このシステムを実現する ためには，支援船舶と同じように海中を航走する AUV を追従 しながら状態を監視し，また AUVの位置や AUVから送られ てくる情報を音響通信で受け取り大気中の無線通信で洋上の支 援船舶または陸上へ送ることが可能な自律型洋上航走体 (ASV: Autonomous Surface Vehicle) [3] [4] が必要となる。本件では このための洋上中継器となる ASVを開発している.

\section{AUV 複数機運用観測システムの概要}

現在は，海中を航走する AUVに対して支援船舶が AUVを 追跡して管制を行っている，海底の精密調査ではAUVは高度 80〜100 [m] 程度まで海底に接近して巡航する. この際，使用す る観測装置にもよるが AUV 1 機の 1 潜航での調査範囲は 1.5 $20\left[\mathrm{~km}^{2}\right]$ 程度であり, 海底面に接近でき精密な調査ができる反 
面，調査可能範囲は狭くなってしまうため，対象海域が広大で ある場合は調査に期間を要してしまう。しかも支援船舶を使用 できる期間が限られるうえに，天候により調査活動ができない 場合も多くある。このため限られた期間での調査効率を向上さ せることを目的に，1隻の支援船舶で AUV を複数機同時に展 開させる調査システムを開発することとなった。具体的には洋 上を自律して AUVを追尾し，また管制に必要な測位などの情 報を無線 LAN や衛星経由で支援船舶に転送する無人機を使っ て，AUVを間接的に監視する手法を構築する.

水中での音響通信は大気中の通信で使用されている電波通信 とは異なり, 伝送距離や範囲が狭い. 一般に通信可能範囲は船舶 から鉛直下方向に角度 $30^{\circ}$ 程度の円すい状に広がる範囲であり, 水深 $500[\mathrm{~m}]$ では水平方向直径 $500[\mathrm{~m}]$ 程度, 水深 $1,000[\mathrm{~m}]$ では水平方向直径 $1,000[\mathrm{~m}]$, 水深 $3,000[\mathrm{~m}]$ では水平方向直 径 $3,000[\mathrm{~m}]$ と水深により水平範囲は変化する. しかしながら, AUV を複数展開しそれぞれが別々な計画測線を航走して AUV 間の距離が数 $[\mathrm{km}]$ 離れてしまう場合は，一つの音響通信可能 範囲にすべての AUV の行動を納めることは難しい. このため に AUV 1 機につき 1 機の ASVが必要となる.

海底資源の調査手法としては, 有望な海域に対して同等性能 を有する巡航型 AUVにより矩形状航走しながらに面的に調査

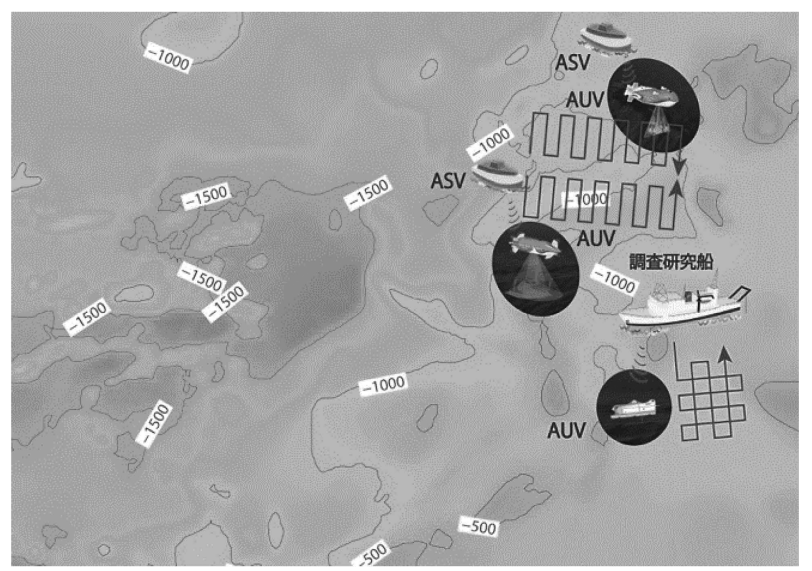

(a) Survey method A (Wide range survey)

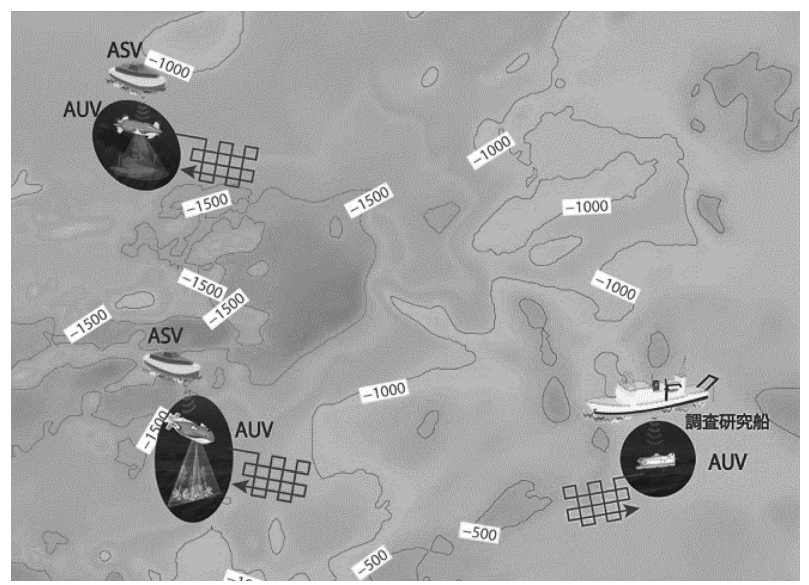

(b) Survey method B (Remarkable point survey)

Fig. 1 Concept of multi AUVs survey system
している間に, 定点観測型 AUV が特徵的な箇所を重点的に調 査する手法 (Fig. 1 (a)), 複数の AUV で散在する特徵的な箇 所を重点的に精査する（海底資源の存在が有望視される箇所に 対して縦横から観測して精度の高いデータを得るようにする) 手法（Fig. 1(b)）などがある.いずれの手法であっても，互い の AUV は数 $[\mathrm{km}]$ 以上の距離で調査活動を行う。このため, 支 援船舶は 1 機の AUV を監視し, ほかの AUVは直上を航走し ている ASVから送信される位置や状態情報により間接的に監 視する.

\section{3. 洋上中継器 (ASV) の概要}

本件で開発する自律型洋上航走体（ASV）は，海中を巡航し ながら調査するAUVを自律して追従するＡSVは追従しなが ら AUVから音響で発信される情報を洋上で受信し, 支援船舶 や陸上へ衛星経由で電波で送信する，追跡対象となる AUVは, 水深 3,000 [m] までの潜航能力を有し， 0.5 2 ノットで巡航し ながら観測調査を行う。このため機体は洋上から AUV を追従 するための十分な速力が必要であるため, ASVの巡航速力は 2 ノット程度とし, 潮流の影響を考慮し最大で 5 ノットの能力と した。また，ASVは海中の AUVの測位や通信を行うために， 音響測位および通信装置を備えている。音響通信装置は海面か らの影響を避けるために一定の深度に設置する必要がある. 機 体の契水は $0.4[\mathrm{~m}]$ と浅いため, キール部を設け, 海面からの距 離を離した位置に音響装置を搭載できるようにしている。さら に AUVからの情報を支援船舶または陸上へ送信するための衛 星通信装置も備えている. ASVの機体規模は, 調査海域までは 機構所有の船舶により AUVと同時に輸送するため, 支援船舶 の甲板に搭載できる大きさとした. ASV 機体の外観を Fig. 2 に, 諸元を Table 1 に示す.

\section{ASV 制御システム}

ASVの制御システムは, 下記の理由で分散化システムとして いる. Fig. 3 に構成図を示す.

（1）システムの抗たん性の向上

ASV は AUVの行動を監視することが任務であるが, ASV

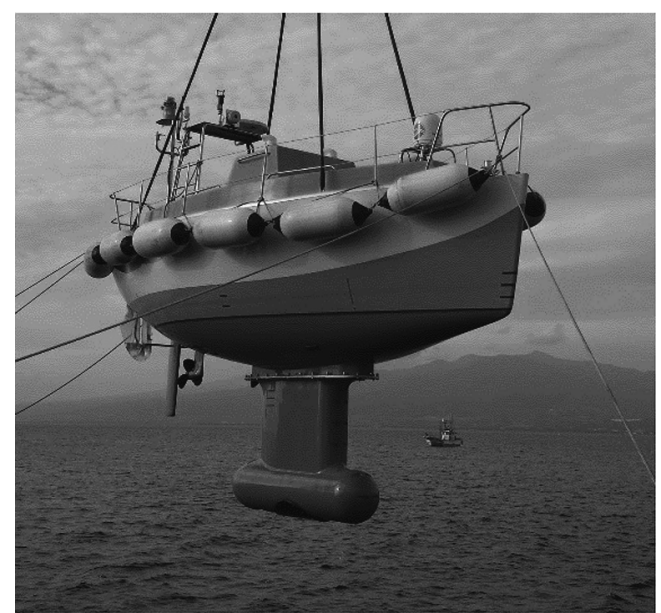

Fig. 2 Overview of ASV 
Table 1 Principal particulars of ASV

\begin{tabular}{|l|l|}
\hline Size : & $6 \mathrm{~mL} \times 2.6 \mathrm{mB} \times 3.2 \mathrm{mH}, \quad$ Draft $0.4 \mathrm{~m}$ \\
\hline Weight in air : & 3 tons \\
\hline Endurance : & 48 hours \\
\hline Max. Speed : & 5 knots \\
\hline Cruising Speed : & 2 knots \\
\hline Generator : & Diesel Engine $11 \mathrm{~kW}$ \\
\hline Actuator : & $\begin{array}{l}\text { Thruster } \times 2 \\
\text { Rudder } \times 1\end{array}$ \\
\hline $\begin{array}{l}\text { Communication } \\
\text { Device : }\end{array}$ & $\begin{array}{l}\text { Sattellite Communication (air), } \\
\text { Wireless LAN (air), } \\
\text { Acoustic Communication (underwater) }\end{array}$ \\
\hline $\begin{array}{l}\text { Navigation } \\
\text { Device : }\end{array}$ & $\begin{array}{l}\text { Satellite Compass, Anemometer, AIS } \\
\text { Acoustic Navication System }\end{array}$ \\
\hline Control : & $\begin{array}{l}\text { Autonomous, } \\
\text { Remotley operated by } \\
\text { communication or wireless LAN }\end{array}$ \\
\hline
\end{tabular}

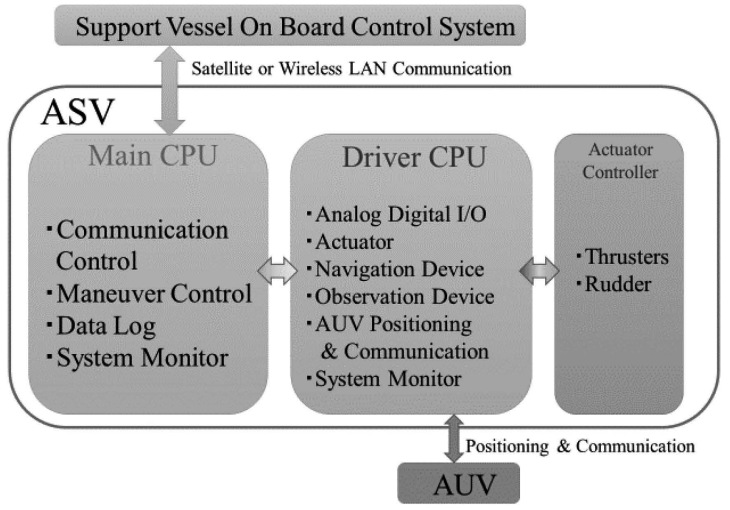

Fig. 3 Configuration of ASV system

の不具合で AUV の行動を妨げてはならない。このため CPU の一つに障害が発生しても可能な限り AUV 追尾を 再開できるよう複数の CPU を用いた分散システムとする。

(2) 機器の拡張性および整備性

ASV 制御システムと支援船舶の ASV 管制装置との通信機 能や機体の運動・自律制御機能を司るメイン CPU と, 航海 計器, 観測装置などの ASV 搭載機器の制御を司る $\mathrm{CPU}$ と アクチユエータの制御を司る CPUによる構成としている。

\section{ASV 運動制御}

ASV の操縦には，支援船舶に設置する管制装置からの無線 LAN または衛星通信による遠隔制御と, プリセットするシナ リオファイルにより航行する自律制御がある。この自律制御は, 基本的な運動を規定した航行コマンドの組み合わせにより行わ れる. 航行コマンドは, ウェイポイント (WP：Way Point, 目 標ポイントへ経路を問わず向かう）航行, ウェイライン（WL： Way Line, 定めた航路に沿って目標ポイントへ向かう）航行, 方位航行, 定範囲保持, AUV 追尾, 停止から構成される. この 航行コマンドは, 基本運動制御の組み合わせにより実行される。 この基本運動制御は，方位角または針路制御，旋回制御，速力

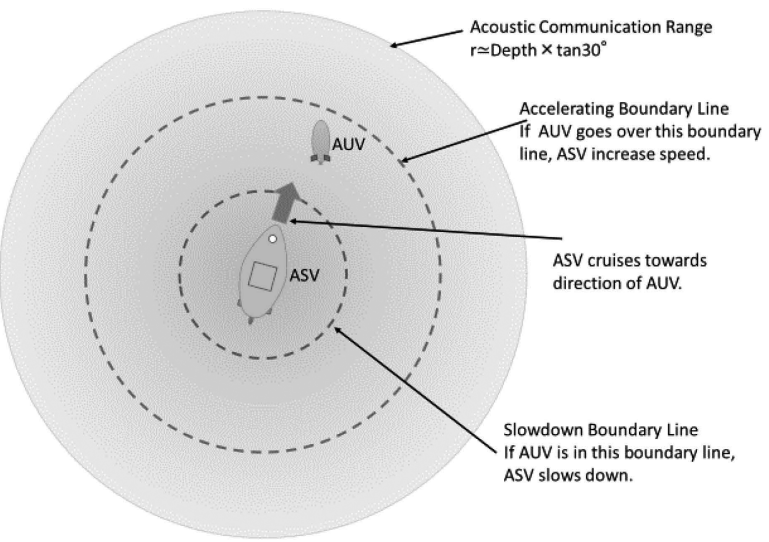

Fig. 4 Concept of decision area for speed control of ASV

制御，停止の 5 とおりから構成される. 各基本運動制御は PID 制御により構成し, 制御ゲインは後述の模型試験の結果を用い て構築したシミュレータによるシミュレーションにより事前調 整した。

ASVの主要機能であるAUV 追尾航行は, AUV を音響で測 位し, その AUVの方向へ向かうように追尾制御を行う。音響 測位は, AUV 搭載のほかの音響機器との干渉等と, 音の伝搬 速度の観点から数秒間隔で行う. ASV が航走する海面と AUV が航走する海中では潮流・風・波等の環境影響が異なるため, ASV，AUV ともに一定速度で航走できるとは限らない。ここ で,「2. AUV 複数機運用観測システムの概要」の章で記述した ように，水中での音響通信は大気中の通信で使用されている電 波通信とは異なり, 伝送距離や範囲が狭い。一般に通信可能範 囲は船舶から鉛直下方向に角度 $30^{\circ}$ 程度の円すい状に広がる範 囲であり, 水深 $500[\mathrm{~m}]$ では水平方向直径 $500[\mathrm{~m}]$ 程度, 水深 $1,000[\mathrm{~m}]$ では水平方向直径 $1,000[\mathrm{~m}]$, 水深 $3,000[\mathrm{~m}]$ では水 平直径 $3,000[\mathrm{~m}]$ と水深により水平範囲は変化する. AUVがこ の範囲から一定時間外れてしまうと, 音響通信途絶となり, 調 查行動を中止して浮上，もしくは亡失することになる。このよ うな事態に陥らないためには, ASV は音響測位が可能な範囲 内 $\left(\right.$ 半径 $\simeq \mathrm{AUV}$ 深度 $\left.\times \tan 30^{\circ}\right)$ に AUV を留めるように機体 の運動を制御する必要がある。制御条件としては，上述した音 響測位可能範囲円に対して仮想判定円を設け，その判定円に対 する AUVの位置により, 速度の増減を判断して, AUVを追 尾するよう機体の運動を制御する，その概念図を Fig. 4 に示 す．音響測位可能範囲は AUV の深度に応じて変化するため判 定円もAUV の深度に応じて範囲が大小する（増速判定円：半径 $\simeq \alpha \times \mathrm{AUV}$ 深度 $\times \tan 30^{\circ}+\beta$, 減速判定円: 半径 $\simeq \alpha \times \mathrm{AUV}$ 深度 $\times \tan 30^{\circ}-\beta, \alpha, \beta$ はパラメー夕). 具体的には, AUV の深度が深くなれば判定円は大きくなり, 浅くなれば小さくな る，図より，最外殼の円は音響測位可能な限界円であり，AUV の外側にある点線円は増速判定円，AUV と ASV の間にある円 が減速判定円となっている. ASV の速度制御は，増速判定円と 減速判定円を境界として 3 と扔りある。 (1) AUV が増速判定円 の外側に位置すると, ASVは AUVに追いつくように, 一定間 隔で速度を増して行く, ただし最大速度に到達した場合は最大 
速度より超えない. (2) 増速判定円と減速判定円の間に AUVが 位置している場合は, ASVの現状の速度を維持する。 (3) AUV が減速判定円の内側に位置すると，ASVは一定間隔で速度を 減じて行く，ただし速度 0 になった場合でも後進はしないでス ラスタを停止する。また, ASVが AUVを追い越した場合は前 進しながら U ターンをして, AUVを後ろから追尾するように する.

\section{6. 模 型 実 験}

実機を使用しての運動制御ゲインの調整には大がかりな試 験になるため時間を要する，また海象条件が一定しないため再 現性がなく効率的な調整を行うことが困難である. ASVの自 律機能や運動制御性能の調整にはシミュレータを用いる。この シミュレータには機体の運動方程式の数式モデルを用いるが, 機体に働く流体力は CFD または模型試験により得る必要が ある。本件では流体力を実機の $1 / 3$ スケール模型を使用した 模型試験により計測した $[5] 〜[7]$. 模型試験では, 平水中の抵 抗, 波浪中の運動, 波浪中の抵抗増加, 舵力 - 推力の計測, 斜 航試験, 旋回運動試験（CMT：Circular Motion Test）, Pure Swaying Test, Pure Yawing Test, Pure Surging Test を実 施した. Fig. 5 は平水中での全抵抗試験結果で, 横軸は速度 の無次元值 (フルード数; $F n=U / \sqrt{(L g)}$, ただし $U$ は速 度, $L$ は模型の全長, $g$ は重力加速度), 縦軸は抵抗の無次元值 $\left(R_{w}^{\prime}=R_{w} /\left(0.5 \rho L B U^{2}\right)\right.$, ただし $R_{w}$ は抵抗, $\rho$ は水の密度, $B$ は全幅）で，図中の丸○一つが 1 回の実験に対応する. 波浪 中の抵抗試験結果を Fig. 6 に示す. 横軸は波長 $\lambda$ を模型長さ $L$ で無次元化した值, 縦軸は抵抗増加 $R_{A W}$ を波振幅 $\xi_{a}^{2}$ の二 乗で無次元化した $R_{A W}^{\prime}=R_{A W} /\left(\rho g \xi_{a}^{2}\left(B^{2} / L\right)\right)$ である. 波浪

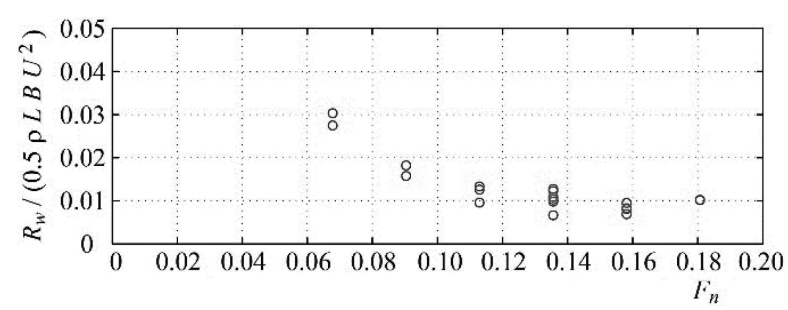

Fig. 5 Fluid drag of ASV model in smooth water

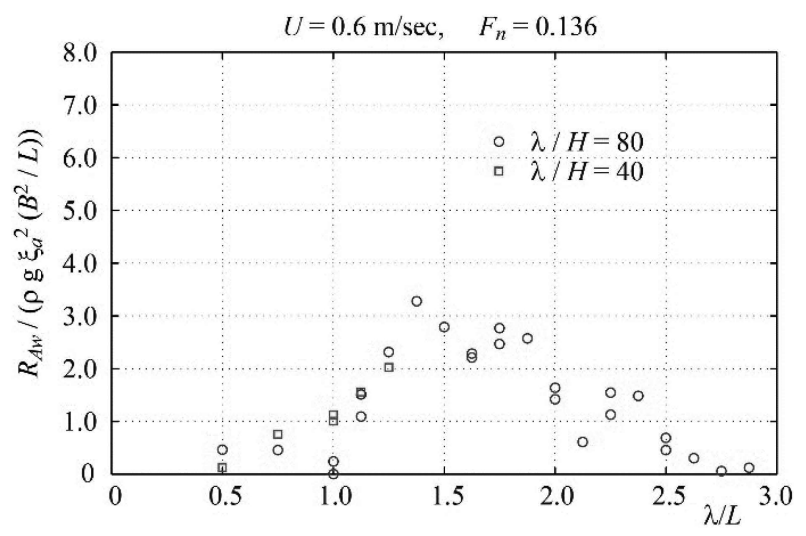

Fig. 6 Fluid drag of ASV model in regular waves

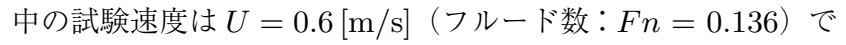
実施した。また，実験に使用した規則波は，波傾斜 $\lambda / H$ を一 定にして行った.ここで， $\lambda$ は波長， $H$ は波高である. 図中の 丸○と四角 $\square$ の一つずつが 1 回の実験に対応する.

平水中全抵抗結果 (Fig. 5) は他船舶の模型試験と比較しても 大きな違いが見出せないが，波浪中抵抗増加（Fig. 6) では $\lambda / L$ $=1.5,2.3$ 付近にピークが二つある特徴的な結果を示している. これは, ASVがキール部を有しているために船底部とキール底 部の円筒胴との干渉により生じたものと推測する.

\section{7. 海域 試 験}

海域試験期間は 2016 年 10 月 31〜 11 月 8 日の 9 日間で実施 した. 今回はこの中で 11 月 6 日に駿河湾奥の水深 $1,400[\mathrm{~m}]$ 程 度の海域で実施した ASVによるAUVの自律追尾試験成果を報 告する. 今回の海域試験の概念を Fig. 7 に示す. 実験では海底 から高度 $80[\mathrm{~m}]$ 程度で航走する AUVに対して音響測位をもと に ASVが自律して追尾航走し, AUV の測位情報を無線 LAN および衛星通信経由で支援船舶に送信する。この間，支援船舶 はほかの小型 AUVの管制を行う.

甲板上で整備中の ASV および追尾対象の AUV「じんべい」 をFig. 8 に示す. 図中で左側奥が ASVで, 右側中央付近が AUV「じんべい」である. AUV「じんべい」の諸元を Table 2 に示す. 全長 $4[\mathrm{~m}]$ で空中重量 1.8 トン, 巡航速力は 2 ノット, 最大潜航深度は $3,000[\mathrm{~m}]$ である.

試験時の海象は曇り, Sea State 2 (波高 $0.1 \sim 0.5[\mathrm{~m}]$ ), 風 速 $2[\mathrm{~m} / \mathrm{s}]$ であった。試験ではまず ASVを海上に展開した後, AUV を潜航させた。試験中の ASVリアルタイム監視モニタの 実験最中の 2016 年 11 月 6 日 11 時 16 分 23 秒時点における, 航跡図を Fig.9 (a) に，ASV およびAUV 情報を Fig. 9 (b) に 示す. Fig. 9 (a) において, 航跡は縦軸を緯度, 横軸を経度とし ている. AUVは Fig. 9 (a) 図中にある Way Point と Way Line で構成する計測線（右下に番号を付与した丸○1-23 (WayPoint) とそれらを順番に結ぶ破線 WayLine）で構成されている）を航 走する. 具体的には, 左下の丸 $\boldsymbol{O}_{1}$ から測線に沿って $1[\mathrm{~km}]$ 北 上し丸○ 2 に至り, そこで $100[\mathrm{~m}]$ 東進して, 丸○ 3 から測線に

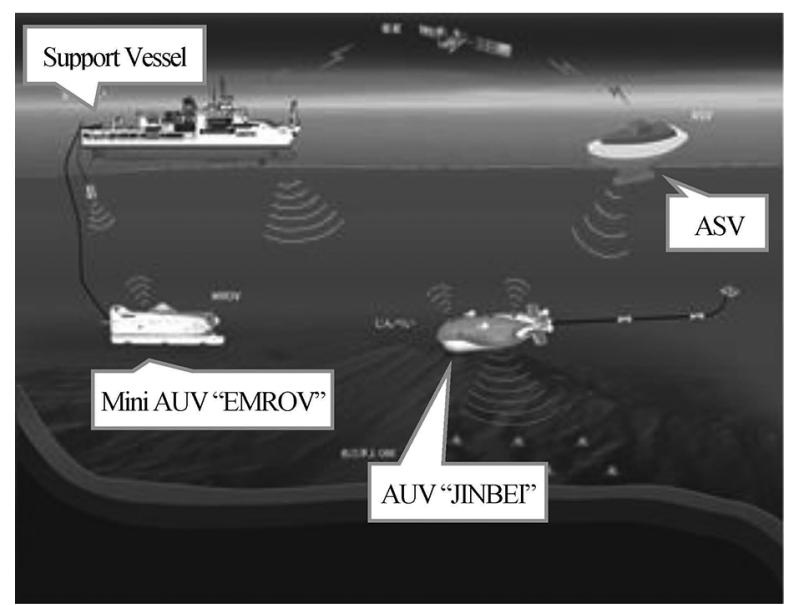

Fig. 7 Concept of sea trial 


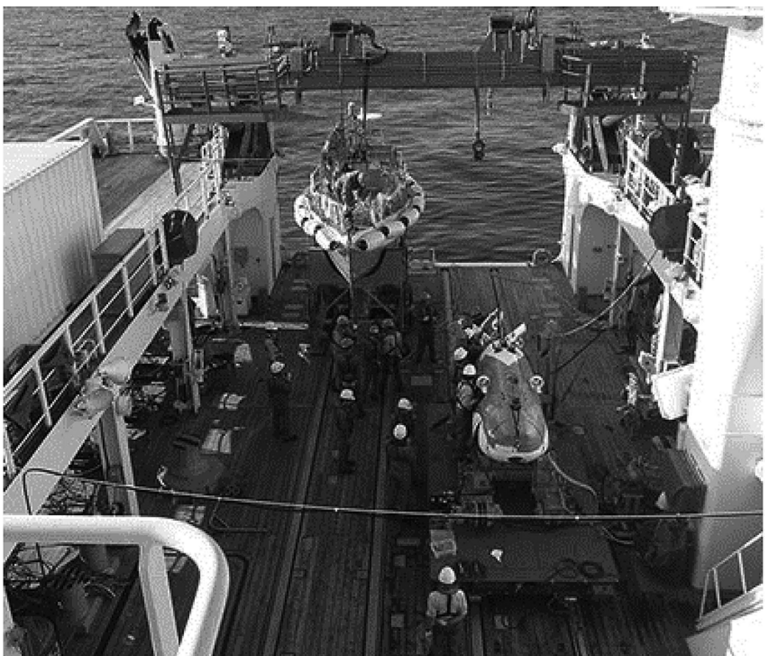

Fig. 8 ASV (left) \& AUV "JINBEI" (right) on deck at sea Trial

Table 2 Principal particulars of AUV "JINBEI"

\begin{tabular}{|c|c|}
\hline Size : & $4 \mathrm{~mL} \times 1.1 \mathrm{mB} \times 1.0 \mathrm{mH}$ \\
\hline Max. Depth & $3,000 \mathrm{~m}$ \\
\hline Weight in air & 1.8 tons \\
\hline Endurance & 10 hours \\
\hline Max. Speed & 3 knots \\
\hline Cruising Speed : & 2 knots \\
\hline Battery : & Li-ion rechargeable, oil filled \\
\hline Actuator & $\begin{array}{l}\text { Thruster } \times 4 \\
\text { Rudder } \times 4\end{array}$ \\
\hline $\begin{array}{l}\text { Communication } \\
\text { Device : }\end{array}$ & Acoustic Communication \\
\hline $\begin{array}{l}\text { Navigation } \\
\text { Device : }\end{array}$ & $\begin{array}{l}\text { Inertial Navication System, Doppler } \\
\text { Velocity Log, Altimater }\end{array}$ \\
\hline Control & Autonomous, Acoustic Remote \\
\hline
\end{tabular}

沿って $1[\mathrm{~km}]$ 南下し丸 $\boldsymbol{口}_{4}$, 更に $100[\mathrm{~m}]$ 東進して丸 $\bigcirc_{5}$ に至る， 以下同様に沿って航走するようにあらかじめプログラムされる. AUVは 1 番から順に Way Line どおりにWay Point をチェッ クポイントとしながら自律航走する. AUVは航路の途中経過 を示した図である.ASV は航走している AUVから定周期で発 信される音響トランスポンダの音を集音することで，AUVの 位置を検出し追尾する. 支援船舶は図の位置で定点保持し, 小 型 AUVのオペレーションを行っている。なお ASVリアル夕 イム監視モニ夕は，ASVが捕捉する AUVの位置（小丸の）と 支援船船の位置のみを表示し，別途支援船舶がオペレーション している小型 AUV を表示することはできない. Fig. 9 (b) 上 部半分の枠内は ASV の状態を表示している。一番上に実験時 の現在時刻（2016 年 11 月 6 日 11 時 16 分 23 秒）を表示して いる。またこの隣では AUVを捕捉中であることの状態表示を している，時刻の下段では，ASVの制御モードが自律制御の AUV 追尾モードであることを表している，通信状態としては， 試験時には，無線 LAN と衛星通信装置が有効状態で，イリジ ウム通信が無効状態であることを示している。ささらに，ASV 位 置 - 速度 · ロール角, ピッチ角 · 舵 - 推進器回転数指令 - 発電

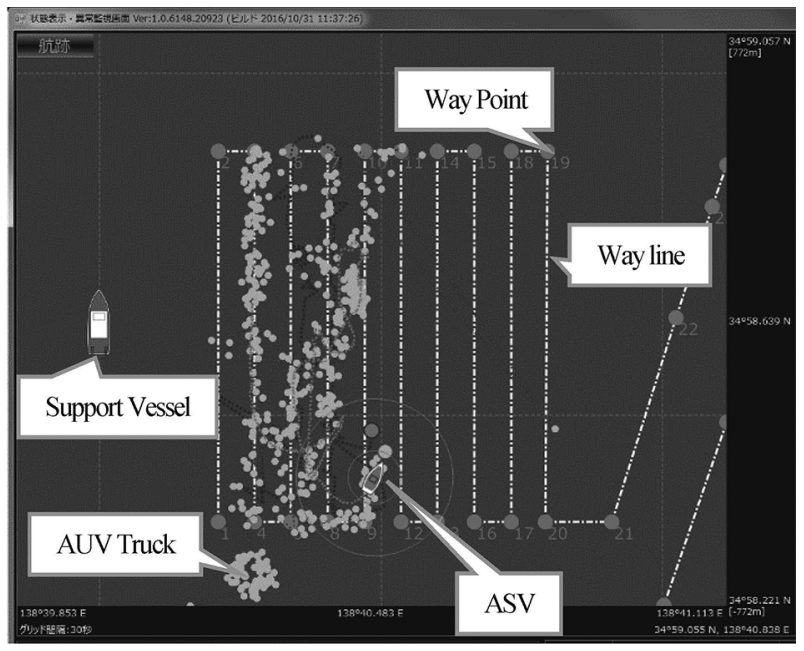

(a) Truck screen

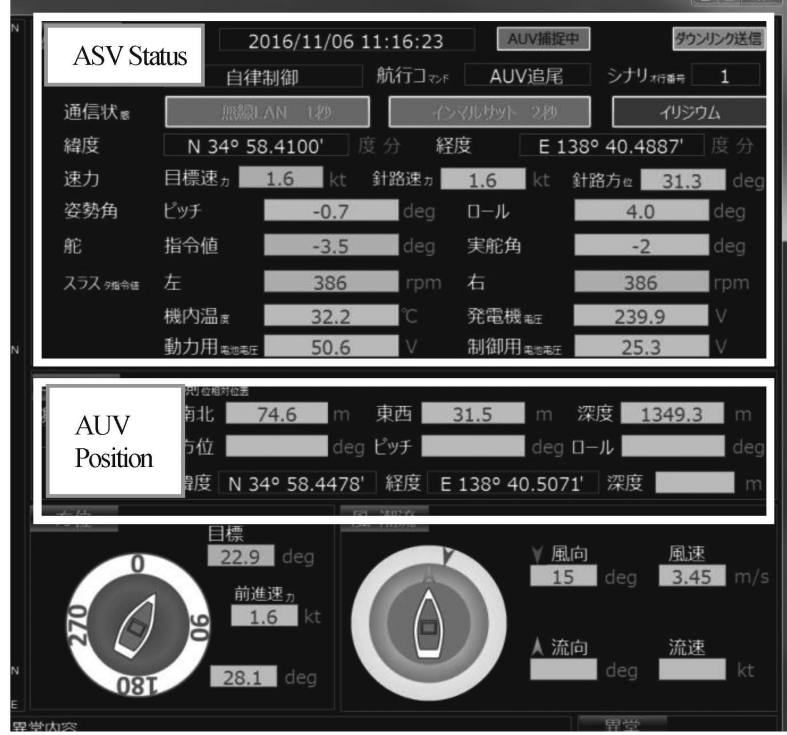

(b) Status screen

Fig. 9 ASV onborad operating monitor

機電圧・機体内温度を表示して状態を監視できるようにしてい る.図の中央の枠内では ASV が測位した AUVの位置情報と して，ASV からの AUV の相対距離・AUV 深度（このときの 潜航深度 $1,349.3[\mathrm{~m}]) \cdot \mathrm{AUV}$ 緯度経度を表示している。

AUV 追尾試験の ASV およびAUV の Fig. 9 と同一航路にお ける航跡を Fig. 10 に示す。縦軸は緯度を，横軸は経度を表し ている.Fig.10（a）において，実線はAUVに搭載している慣 性航法装置（INS：Inertial Navigation System）によって得た 緯度経度を表している．AUVは支援船舶より海面に展開された 後，旋回しながら目標深度（1,300[m]）近くまで潜航する。こ のため潜入開始後，航跡は渦を巻いたような軌跡になる。目標 深度に達すると Way Line に沿って航走する．航走終了後はま た旋回しながら浮上するため, 終了地点でも航跡は渦を巻いて いる. ASV の航跡（破線）は GPS による測位情報を表してい る.また，Fig. 10 (b)においても，ASVの航跡（破線）は GPS 


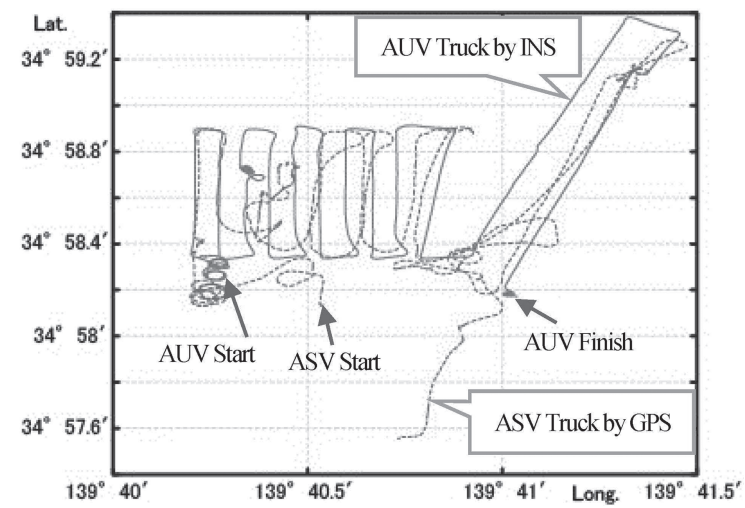

(a) Truck of ASV(GPS) \& AUV(INS)

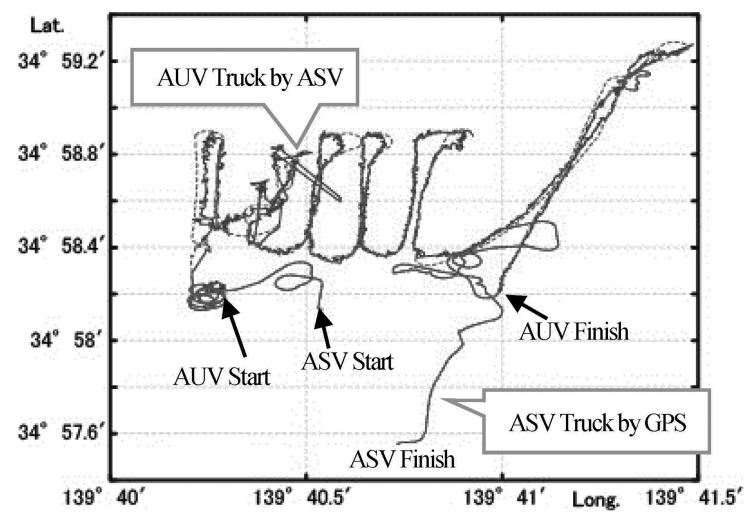

(b) Truck of ASV(GPS) \& AUV(ANS)

Fig. 10 Truck of ASV and AUV at sea trial

による測位情報を表している。ただし，実線は AUVを ASV から音響測位装置 (Acoustic Navigation System) により測位 した結果の航跡を表している．海中の音を動摇している海面の 機体で計測するために誤差が生じるため航跡がジグザグな航跡 となる．また時には音飛びとして大きく異なる位置を誤って測 位する場合もある。しかしながら測位は比較的短い周期（10 秒 前後) で行うため, 一度誤測位があっても次の測位で修正され て，ASV は大きな航路変更をすることなく AUVを追従する. 両図の慣性航法装置による航跡（AUV 搭載による直接位置検 出）と音響測位装置（ASV からの間接位置検出）による位置計 測の航跡で差があるものの，4.ASVの運動制御で記述したよう に，音響通信が可能な範囲であれば AUVを十分捕捉できるた め ASV は AUV の直上に恒に位置していなくても追尾が可能 であることが示された。このような差異が生じた原因としては, 機体規模が支援船舶と比較して $1 / 20$ と小さいために波浪階級 が小さくても機体が動摇してしまうことに起因していると考え る. 今後 ASV からの測位情報を用いて AUV の慣性航法装置 の位置誤差を減少させるための補完データとして使用するため に，測位精度を向上することが課題である.

試験時の ASV と AUV の位置関係の時系列を表すグラフを Fig. 11 に示す. 図は上から, ASV と AUV 相対距離および増 速判定境界, 減速判定境界 $「 \mathrm{~m}\rfloor$, AUV の深度 $「 \mathrm{~m} 」$, ASV の速 度「knot」を表している。横軸は経過時間「sec」である. ASV と AUV の相対位置が増速判定境界を上回れば増速を, 減速限

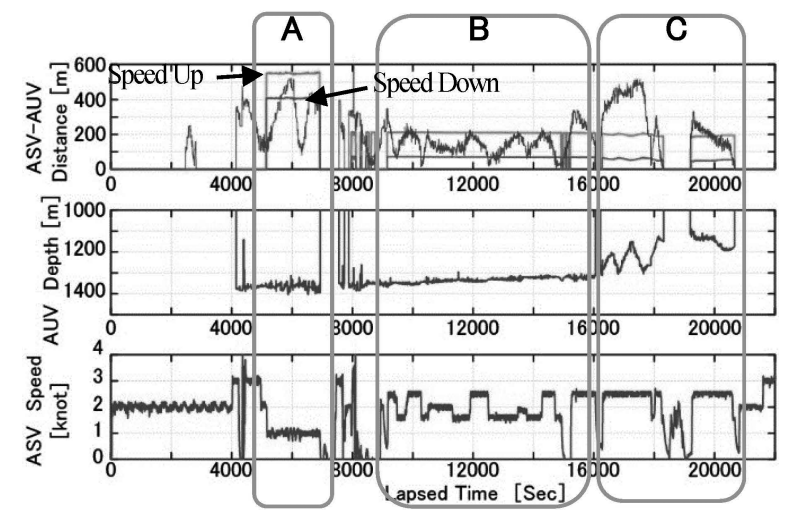

Fig. 11 Time series of ASV-AUV distance (upper), AUV depth (middle) and ASV speed (bottom) at sea trial

界を下回れば減速をするよう ASVはプログラムされている，た だし，今回は試験で状態確認をするために ASV の速度の下限 界を 1 ノット，上限界を 2.5 ノットとした．図中の A の枠内の 状態について，AUVは 2 ノットで航走している.Fig. 4 で示し た従来の増速減速判定円を使用して ASV の追従性能を確認し た. 深度 $1,300[\mathrm{~m}]$ では判定円の半径は深度の約半分であり範 囲が大きくなっているため ASV は AUV をほとんど減速範囲 未満で捕捉することができ，速度の下限界の 1 ノットで追従し ている. B の枠内では意図的に判定円の半径を小さくして相対 距離の変化による ASV の挙動を確認した. その結果, 相対距 離が判定円を行き来することで, ASV の速度も増減することが 確認できた，Cの枠内では AUVの速度を 3 ノットとし, 意図 的に ASVが追いつけない状態にして ASV の挙動を確認した。 相対距離が増速判定円を常に超えているため, ASV は最大速力 で追従した．AUVの直上に位置することができなくても AUV を音響測位範囲に捕捉できている限り ASV は AUV と通信可 能であった。多くの場合計測線は矩形状の折り返しから構成さ れるため, AUVが先行する場合であっても ASV は AUVを 音響通信可能な範囲内に留めておくことが可能であることが分 かった．また， C 枠内で AUVの剁度が浅くなるに従って増速 減速判定円の半径も変化することも確認できた. 途中で判定円 が欠落している箇所は他処理のために ASV の音響通信装置を 停止したことによる.

\section{8.おわりに}

ASVの開発は本稿で紹介した試験をもって試作機としての 所期の成果を得たため, 実証機の開発へと段階が移った。本試 験で確認できた機体制御プログラムはそのまま実証機へと引き 継いだ。また試作機では試験用プラットフォームとして排水量 を大きくしたが，実証機では搭載物や機能を絞り込み小型化を 図った。今後は実証機で運用性能を評価していく.

謝 辞 ASVの海域試験に際して，支援いただいた，海洋調 查船「かい上う」, 海洋地球研究船「みらい」, 海底広域研究船 「かいめい」の船長はじめ乗組員の方々には安全に試験を遂行し ていただき感謝いたします。

本研究 (の一部) は, 総合科学技術・イノベーション会議の 
$\operatorname{SIP}($ 戦略的イノベーション創造プログラム)「次世代海洋資源調 査技術」によって実施されました。

\section{参 考 文 献}

[1] T. Aoki, S. Tsukioka, et al.: "Advanced Technologies for Cruising AUV URASHIMA," International Journal of Offshore and Polar Engineering, vol.18, no.2, pp.81-90, 2008.

[2] 次世代海洋資源調査技術（海のジパング計画）, 内閣府， 2015.

[3] R.R. Williams: Design and Experimental Evaluation of an
Autonomous Surface Craft to support AUV Operations. Massachusetts Institute of Technology, 2007.

[4] 鈴木，須藤，ほか：“USV を経由して UUV からソーナー画像をリア ルタイムデー夕伝送する試験”，IHI 技法，vol.56, no.1, pp.34-40, 2016.

[5] 元良: 船体運動力学 (電子訂正版). 日本船舶海洋工学会, 2007 .

[ 6 ] 安川, 金子, ほか：P29 船舶操縦性予測モデルの標準化に関する研究 委員会報告書, 日本船舶海洋工学会, 2012 .

[ 7 ] 安川, 金子, ほか：P34 船舶操縦性予測モデルの高度化に関する研究 委員会報告書, 日本船舶海洋工学会, 2014 .

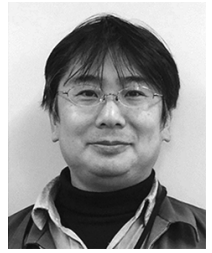

百留忠洋（Tadahiro Hyakudome）

2000 年九州大学大学院総合理工学研究科大気海洋 環境システム学専攻博士後期課程修了. 博士 (工 学). 2000 年海洋科学技術センター (現: 国立研究 開発法人海洋研究開発機構) 入所, 現在に至る. 日 本船舶海洋工学会, 炭素材料学会会員.

（日本ロボット学会正会員）

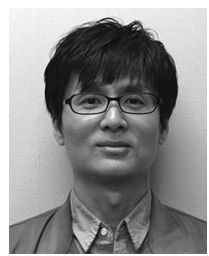

\section{澤 隆雄 (Takao Sawa)}

1998 年名古屋大学工学研究院修了. 1998 年海洋科 学技術センター (現: 国立研究開発法人海洋研究開 発機構) 入所, 現在に至る. 2007 年電気通信大学博 士 (工学)，海洋音響学会，電子情報通信学会会員.

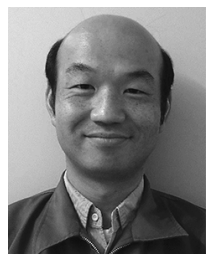

渡邊佳孝（Yoshitaka Watanabe）

2009 年東京海洋大学博士課程修了. 博士 (工学). 2002 年海洋科学技術センター（現：国立研究開発 法人海洋研究開発機構）入所, 現在に至る. 海洋音 響学会，日本音響学会会員。

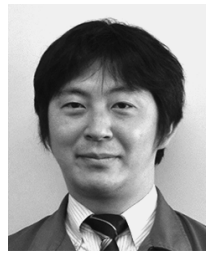

中谷武志 (Takeshi Nakatani)

2009 年東京大学大学院工学系研究科環境海洋工学 専攻博士課程修了. 博士 (工学)。2011 年独立行政 法人海洋研究開発機構（現: 国立研究開発法人海洋 研究開発機構）入所，現在に至る.

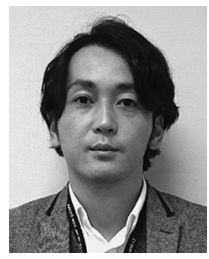

\section{菅 良太郎 (Ryotaro Suga)}

2014 年千葉大学大学院工学研究科博士後期課程修 了. 博士 (工学). 2015 年国立研究開発法人海洋研 究開発機構入所, 現在に至る. 電気情報通信学会, IEEE 会員.

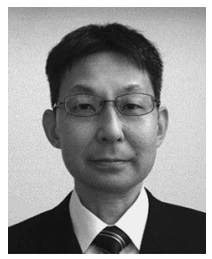

山内由章（Yoshiaki Yamauchi）

1995 年東北大学大学院博士後期課程修了. 博士 (工 学). 1995 年三菱重工業株式会社入職, 現在に至る. 日本船舶海洋工学会会員.

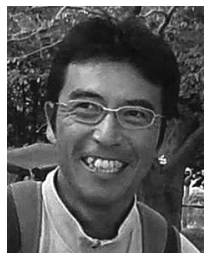

吉田 弘（Hiroshi Yoshida）

1999 年金沢大学自然科学研究科修了. 博士 (理学). 2002 年海洋科学技術センター（現：国立研究開発 法人海洋研究開発機構）入所，現在に至る. IEEEOES, 電子情報通信学会, 海洋理工学会会員.

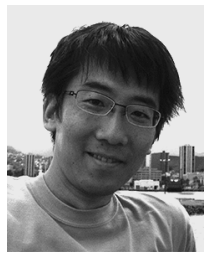

中野善之 (Yoshiyuki Nakano)

2004 年北海道大学大学院地球環境科学研究科修了. 博士 (地球環境科学). 2009 年独立行政法人海洋 研究開発機構（現：国立研究開発法人海洋研究開 発機構）入所，現在に至る. 日本海洋学会, America Geophysical Union, European Geosciences Union 会員.

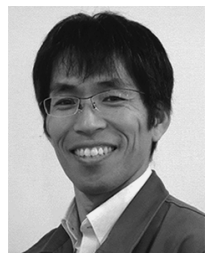

福田達也（Tatsuya Fukuda）

2000 年横浜国立大学卒業. 学士. 2009 年独立行政 法人海洋研究開発機構（現: 国立研究開発法人海洋 研究開発機構）入所，現在に至る.

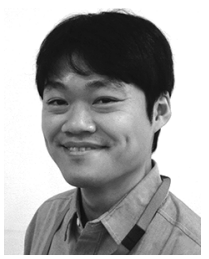

\section{松本 宙 (Hiroshi Matsumoto)}

2009 年北海道大学環境下学院修了. 修士. 2015 年 国立研究開発法人海洋研究開発機構入所，現在に 至る.

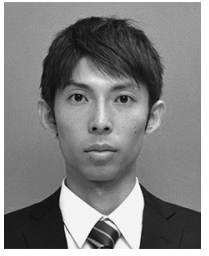

依田貴志（Takashi Yoda）

2017 年横浜国立大学大学院工学府システム総合工 学専攻海洋宇宙システム工学コース博士前期課程修 了. 修士. 2017 年株式会社三井造船昭島研究所入 職, 現在に至る. 研究時は海洋研究開発機構研究員. 日本船舶海洋工学会, 日本航海学会会員.

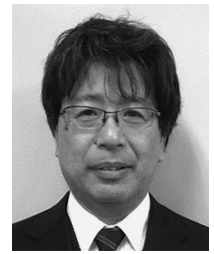

\section{奥田幸人（Yukihito Okuda）}

1995 年大阪大学大学院博士前期課程修了. 修士. 1995 年三菱重工業株式会社入職，現在に至る。日 本機械学会会員. 


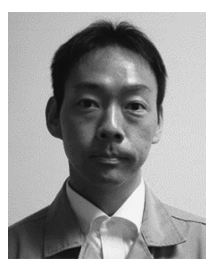

\section{江口和樹（Kazuki Eguchi）}

2008 年熊本大学大学院博士後期課程修了. 博士 (工 学). 2008 年三菱重工業株式会社入職, 現在に至る. 日本機械学会, 計測自動制御学会会員.

森 英男 (Hideo Mori)

1985 年大阪大学大学院博士前期課程修了. 修士. 1985 年三菱重工業 株式会社入職, 現在に至る.

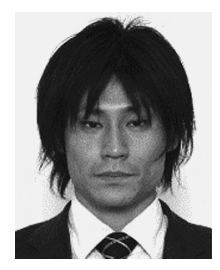

黒岩良太（Ryota Kuroiwa）

2004 年九州大学大学院博士前期課程修了. 修士. 2004 年三菱重工業株式会社入職，現在に至る。日 本船舶海洋工学会会員. 